\title{
Gender blind? An analysis of global public- private partnerships for health
}

Sarah Hawkes ${ }^{1 *}$ D, Kent Buse ${ }^{2}$ and Anuj Kapilashrami ${ }^{3}$

\begin{abstract}
Background: The Global Public Private Partnerships for Health (GPPPH) constitute an increasingly central part of the global health architecture and carry both financial and normative power. Gender is an important determinant of health status, influencing differences in exposure to health determinants, health behaviours, and the response of the health system.

We identified $18 \mathrm{GPPPH}$ - defined as global institutions with a formal governance mechanism which includes both public and private for-profit sector actors - and conducted a gender analysis of each.

Results: Gender was poorly mainstreamed through the institutional functioning of the partnerships. Half of these partnerships had no mention of gender in their overall institutional strategy and only three partnerships had a specific gender strategy. Fifteen governing bodies had more men than women - up to a ratio of 5:1. Very few partnerships reported sex-disaggregated data in their annual reports or coverage/impact results. The majority of partnerships focused their work on maternal and child health and infectious and communicable diseases - none addressed non-communicable diseases (NCDs) directly, despite the strong role that gender plays in determining risk for the major NCD burdens.

Conclusions: We propose two areas of action in response to these findings. First, GPPPH need to become serious in how they "do" gender; it needs to be mainstreamed through the regular activities, deliverables and systems of accountability. Second, the entire global health community needs to pay greater attention to tackling the major burden of NCDs, including addressing the gendered nature of risk. Given the inherent conflicts of interest in tackling the determinants of many NCDs, it is debatable whether the emergent GPPPH model will be an appropriate one for addressing NCDs.
\end{abstract}

Keywords: Global public private partnerships for health, Gender, Mainstreaming, Non-communicable diseases

\section{Background}

Gender is an important determinant of health status influencing, at a minimum, rates of risk-exposure to common drivers of ill-health, health-care seeking patterns, and the nature of the health system's response to illness. It is with the latter that we are concerned in this paper. We focus on global public-private partnerships for health (GPPPH) since they are an important component of the global health architecture, are seen as having significantly increased the resources available for global health [1-4], and are promoted by some as offering critical opportunities to improve "efficiency, equity, value

\footnotetext{
* Correspondence: s.hawkes@ucl.ac.uk

${ }^{1}$ Institute for Global Health, University College London, 30, Guilford Street,

London WC1N 1EH, UK

Full list of author information is available at the end of the article
}

for money, and outcomes in global public health" [5]. Moreover, the public-private partnership approach has been encouraged as a mechanism for overcoming failures of both market and state [6] as well promoting efficiency in service delivery [6] and innovation in and access to technological resources [7]. Given the importance of the GPPPH model within global health activities, and the central role that gender plays as a determinant of health, the question we address in our paper is how and to what extent the GPPPH focus on issues of gender within their priorities, policies and programmes.

The GPPPH have become increasingly powerful actors within global health: funds allocated to the two largest GPPPH (Global Fund to Fight AIDS, TB and Malaria GFATM- and GAVI) have increased from US\$1.67 billion to US $\$ 4.9$ billion over the 10-year period 2005 and 
2015 - an almost three-fold rise. In total, these two partnerships currently receive $14 \%$ of external global health financing [8]. Nonetheless, the partnership model has been criticised as implying privatisation by stealth [9], of disrupting the focus and governance of country level health systems [10-12], of unduly influencing international norm-setting [13, 14] and of promoting an overly narrow technical focus on solutions for health problems [15, 16] . Notwithstanding such criticism, public-private-interaction is likely to grow across all sectors, including health, as countries and international organisations mobilise to achieve the sustainable development goals (SDG) by 2030. The United Nations Agenda 2030 for Sustainable Development actively advocates for countries to "Encourage and promote effective public, public-private and civil society partnerships, building on the experience and resourcing strategies of partnerships." [17] . Moreover, the Addis Ababa Agenda on Financing For Development identifies a critical role of private finance for development, including through the mechanism of public-private partnerships [18].

Although there are no agreed upon definitions of GPPPH [19] a commonly used definition was proposed by Buse and Harmer as "relatively institutionalised initiatives, established to address global health problems, in which public and for-profit private sector organisations have a voice in collective decision-making." [20] We use this definition for identifying GPPPH for inclusion in our analysis.

Gender is recognised as a significant driver of health outcomes - both as an influence in its own right, and through its interaction with other determinants of inequity and vulnerability. Payne [21] has characterized gender influences on health in three domains: differences in exposure to social determinants of health (e.g., poverty or the health risks of employment); health behaviours (e.g., diet, tobacco or alcohol use, patterns of care seeking); and the response of the health system to the different needs of men and women.

Despite the profound influence that gender exerts on health, the ability of global health institutions to recognise, understand and address the influence of gender on health outcomes has been characterised as "missing, misunderstood and sometimes mainstreamed" [22]. Gender mainstreaming - a strategy for promoting gender equity through "research, legislation, policy development and in activities on the ground" [23] - has been part of global policy discourse for more than 35 years [24] and the United Nations (UN) Economic and Social Council agreed to mainstream a gender perspective in all $\mathrm{UN}$ policies and programmes with the ultimate goal of gender equality [25]. The concept and practice of gender mainstreaming is contested. Critics in particular emphasise how an 'integrationist' and 'technocratic' approach adopted by state and international bureaucracies, waters down its transformative intent [26]. Yet, the contributions of GM in placing gender as "a critical axis of power" (ibid) and improving effectiveness of policies "by making visible the gendered nature of assumptions, processes and outcomes" [27] are widely acknowledged.

Reviews of how international health organisations "do gender" have predominantly focused on major intergovernmental agencies [21] and to date there have been few evaluations of how the GPPPH take gender equity into account when prioritising the focus of their work, their governance structures, or their ways of implementing activities. Hanefeld et al. reviewed the impact of three global health initiatives on health equity, with a specific focus on HIV and women, but concluded that there was little evidence of long-term impact on equity [28]. More recently, Gideon and Porter reviewed public-private partnerships with an emphasis on women's health, and noted the lack of evaluation of partnerships with respect to their impact on various aspects of equity, including gender [29].

Within this paper we take a holistic approach to gender equity in health and analyse how the GPPPH address gender- both as a determinant of health, and as an influence on health system priorities. We use the methodology of gender analysis to systematically identify and critically appraise gender policies and commitments of GHPPP to assess key gaps and address gender related health inequities [30].

\section{Methods}

We included 18 GPPPH that fit the definition of Buse and Harmer [20]. The partnerships were identified from previous publications, WHO documents on partnerships and collaboration [31], and from email communications with experts in public private partnerships, global health and global health governance. We also posted a question on Twitter to try and identify partnerships fitting the Buse/Harmer definition (and identified one GPPPH this way). We did not include public-private partnerships that operate only at national (or sub-national) levels, or those partnerships that do not have a formal governance mechanism that includes both the public sector and the for-profit private sector.

We conducted a gender analysis of the priorities, focus and institutional mechanisms of each of the $18 \mathrm{GPPPH}$. The analysis relied upon reviewing the publicly-available documents from each partnership found on their websites. We analysed the following: references to or working definition of gender used by the GPPPH; presence of a specific gender strategy; gender breakdown of the governing board; presentation of gender-disaggregated service delivery and/or health outcome and impact data. We reviewed the make-up of the governing boards, and 
categorised board members as belonging to: the public sector, i.e., national government or multilateral system; the private for-profit sector; or "other" - i.e., academics, representatives of Foundations, non-governmental or civil society organisations, consultants (including now retired staff from other sectors), and people whose affiliations were not fully clear. ${ }^{1}$ In some cases, people shifted their position from representing public to private sectors (occasionally, vice-versa) as they changed jobs; we categorized them according to their current official position.

Our methodological approach to analyzing the extent to which gender is mainstreamed within health institutions predominantly focused on the extent to which a gender perspective is incorporated into organizational governance, structure and policies [32, 33]. Moving beyond this established approach, we were additionally concerned with the extent to which gender played a part in institutional priorities - were the GPPPH addressing the impact of gender on the overall illness burden? As a final methodological step, we compared the focus of the $18 \mathrm{GPPPH}$ with the current evidence of global burden of disease, disaggregated by sex, and reviewed whether the
GPPPH address the main determinants of morbidity, mortality and well-being. In Figs. 1 (men) and 2 (women) we mapped GPPPH focus on to the global burden of disease charts produced by the Institute for Health Metrics and Evaluation [34]. These charts show the proportional distribution of burden of disease, as measured by disability adjusted life years (DALYs), and are divided (by IHME) into three categories: noncommunicable diseases including mental health (left hand side of Figure); maternal and communicable diseases (top right); and violence and injury (bottom right). The logos of each GPPPH are mapped onto the burden of disease charts. Exact mapping was not possible since many of the partnerships cover several health problems (e.g., developing new diagnostics for infectious diseases, delivering vaccines against infection, or improving maternal health), but the placement of partnership logos gives a general idea of the main areas of work.

\section{Results}

A full list of these GPPPH is given in Table 1 along with their main focus area of work - mainly covering product

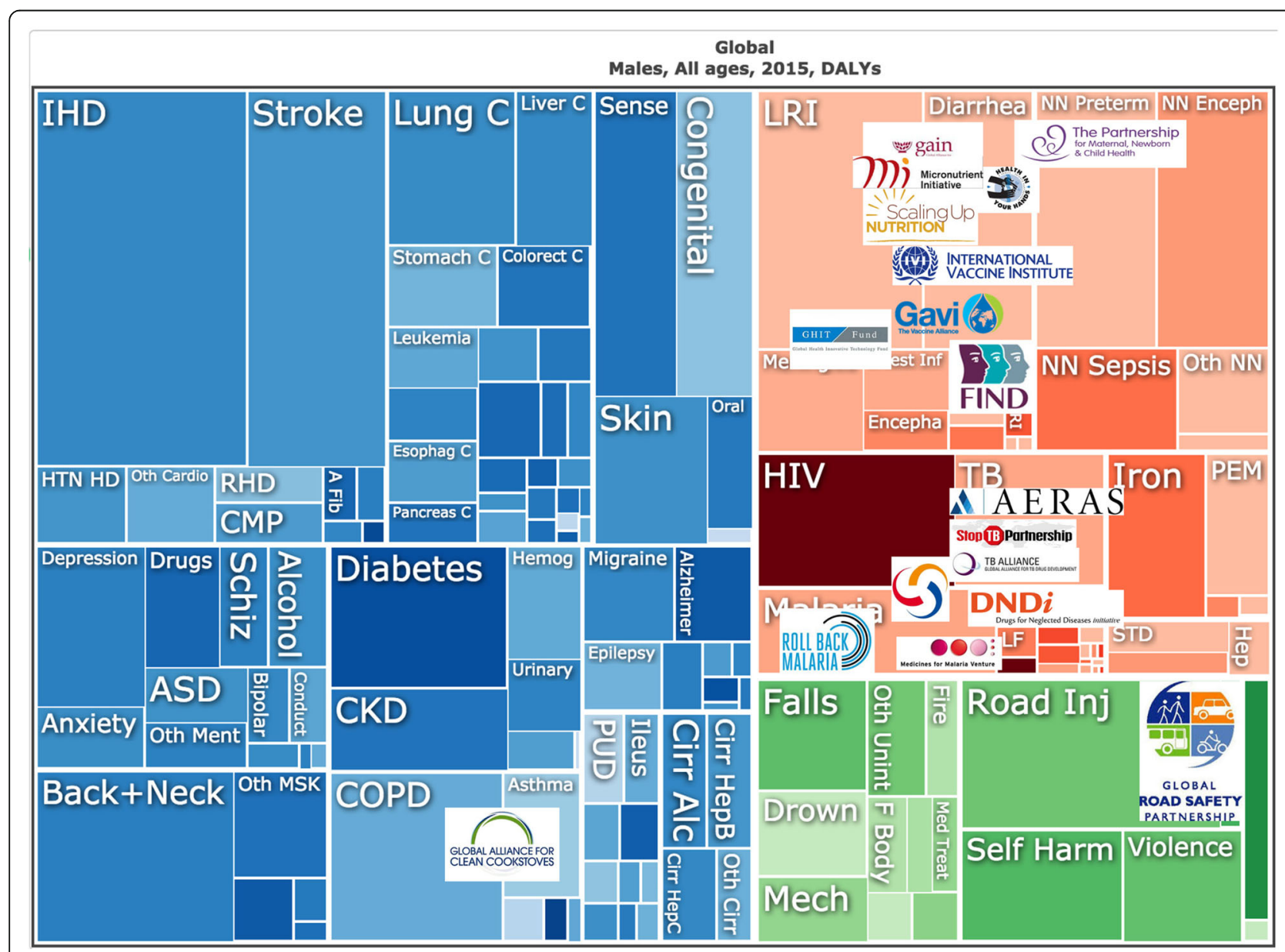

Fig. 1 DALY distribution and GPPPH area of work; men. Data and chart available at: https://vizhub.healthdata.org/gbd-compare/ 


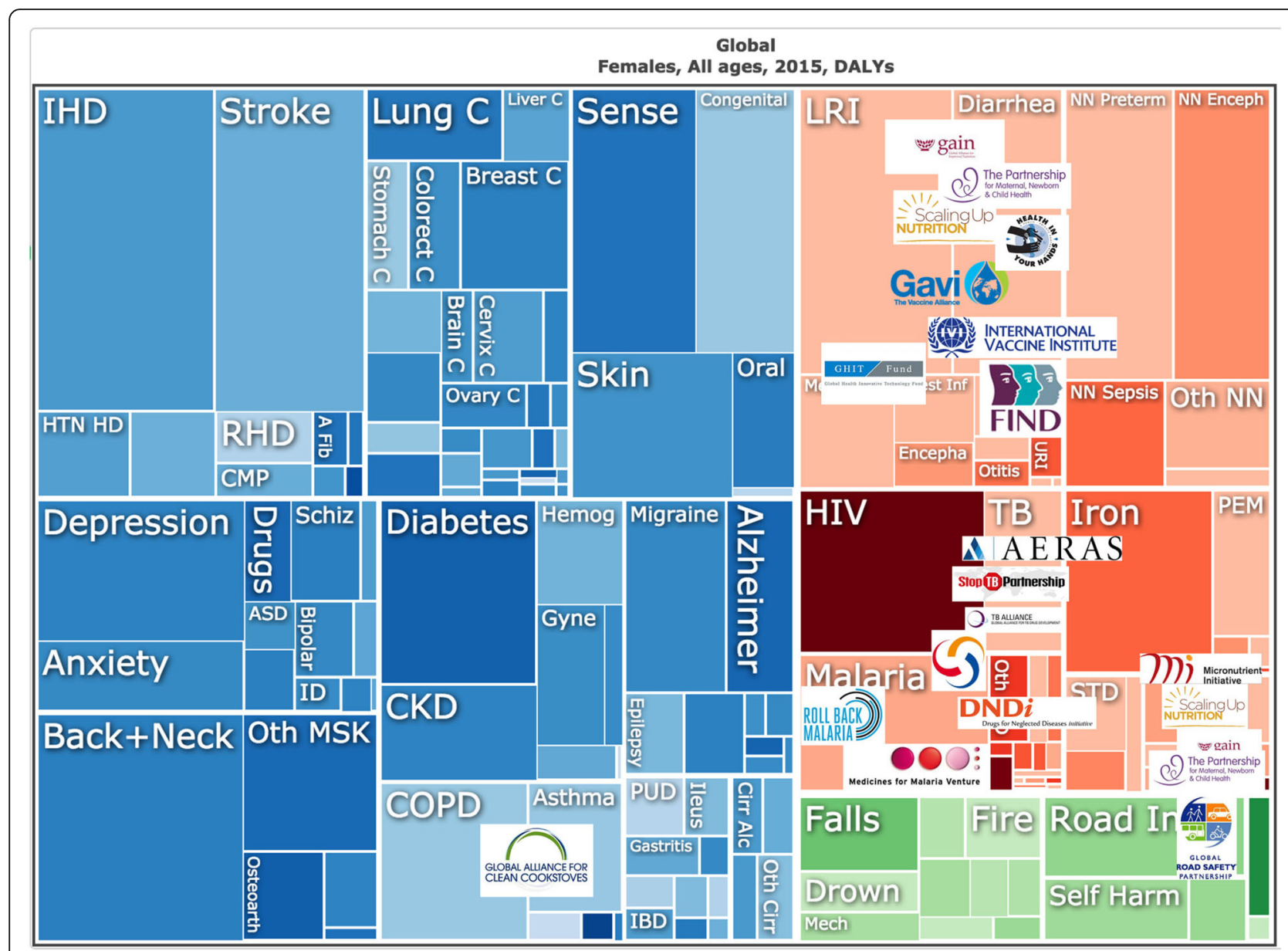

Fig. 2 DALY distribution and GPPPH area of work; women. Data and chart available at: https://vizhub.healthdata.org/gbd-compare/

development and access; strengthening systems including health systems; or addressing the underlying determinants of ill-health.

Table 2 presents the results of the gender analysis of the $18 \mathrm{GPPPH}$. Three partnerships (GAVI, Global Fund for AIDS, TB and Malaria - The Global Fund - and Global Alliance for Clean Cookstoves) had a specific gender strategy, although the understanding of gender varied significantly across the three. For GAVI, gender was defined as "the characteristics of women and men which are socially constructed" while the Global Alliance for Clean Cookstoves emphasised the need to focus their work on girls and women. The Global Fund in its Gender Equality Strategy [35] commits to fund proposals "that scale up services and interventions that reduce gender-related risks and vulnerabilities to infection ... and address structural inequalities and discrimination". The Global Fund was the only partnership to highlight the specific needs of transgender populations (see Table 2) in a policy document, although the Stop TB/ UNAIDS Gender Assessment Tool includes transgender health issues as a focus area.
The Stop TB Partnership did not have a published gender strategy, but its overall strategy document defined gender-sensitive policies and gender-specific approaches and stressed that these should "strengthen the response to fulfil the right to health of women and girls, men and boys in all their diversity" [36]. Stop TB, jointly with UNAIDS, has recently released a gender assessment tool to assess country-level HIV and TB epidemics and guide development of gender sensitive and transformative responses [37].

A further five GPPPH (GAIN, RBM, SUN, Micronutrient Initiative and $\mathrm{PMNCH}$ ) specifically mentioned gender and the health of women and girls in their overall strategy document. None of these partnerships included any mention of a specific focus on the health of men and boys.

Half the GPPPH (AERAS, DNDi, FIND, Global Health Innovative Technology Fund, The Global Road Safety Partnership, International Vaccine Institute, Medicines for Malaria Venture, TB Alliance and the Global PPP for Handwashing) made no mention of gender in their overall strategy, had no gender strategy, and did not allude 
Table 1 general focus of each partnership included in the analysis

\begin{tabular}{|c|c|c|}
\hline $\begin{array}{l}\text { Global Health Public-Private } \\
\text { Partnership }\end{array}$ & Website address & Mission \\
\hline AERAS & http://www.aeras.org/ & $\begin{array}{l}\text { To develop new, effective TB vaccines that are affordable and accessible to all who } \\
\text { need them. }\end{array}$ \\
\hline DNDi & http://www.dndi.org/ & $\begin{array}{l}\text { To develop new drugs or new formulations of existing drugs for people living with } \\
\text { neglected diseases. }\end{array}$ \\
\hline FIND diagnostics & http://www.finddx.org/ & $\begin{array}{l}\text { To turn complex diagnostic challenges into simple solutions to overcome diseases of } \\
\text { poverty and transform lives. }\end{array}$ \\
\hline gain & $\begin{array}{l}\text { http:// } \\
\text { www.gainhealth.org/ }\end{array}$ & $\begin{array}{l}\text { To reduce malnutrition through sustainable market-based strategies aimed at improv- } \\
\text { ing the health and nutrition of populations at risk. }\end{array}$ \\
\hline GAVI & http://www.gavi.org/ & $\begin{array}{l}\text { To save children's lives and to protect people's health by increasing equitable use of } \\
\text { vaccines in lower-income countries. }\end{array}$ \\
\hline $\begin{array}{l}\text { Global Health Innovative } \\
\text { Technology Fund }\end{array}$ & $\begin{array}{l}\text { https:// } \\
\text { www.ghitfund.org/ }\end{array}$ & $\begin{array}{l}\text { To facilitate international partnerships that bring Japanese innovation, investment, and } \\
\text { leadership to the global fight against infectious diseases and poverty in the developing } \\
\text { world. }\end{array}$ \\
\hline Global Road Safety Partnership & $\begin{array}{l}\text { http:// } \\
\text { www.grsproadsafety.org/ }\end{array}$ & $\begin{array}{l}\text { To dedicate its partnership to the sustainable reduction of road-crash death and injury } \\
\text { in low- and middle-income countries, which suffer } 90 \text { per cent of the } 1.3 \text { million annual } \\
\text { deaths and } 50 \text { million serious injuries that arise from road crashes. }\end{array}$ \\
\hline International Vaccine Institute & http://www.ivi.int/ & $\begin{array}{l}\text { To discover, develop, and deliver safe, effective and affordable vaccines for global } \\
\text { public health. }\end{array}$ \\
\hline Medicines for Malaria Venture & http://www.mmv.org/ & $\begin{array}{l}\text { To reduce the burden of malaria in disease-endemic countries by discovering, develop- } \\
\text { ing and facilitating delivery of new, effective and affordable antimalarial drugs. }\end{array}$ \\
\hline Roll Back Malaria & $\begin{array}{l}\text { http:// } \\
\text { www.rollbackmalaria.org/ }\end{array}$ & $\begin{array}{l}\text { To reduce malaria morbidity and mortality by reaching universal coverage and } \\
\text { strengthening health systems. }\end{array}$ \\
\hline Scaling Up Nutrition & $\begin{array}{l}\text { http:// } \\
\text { scalingupnutrition.org/ }\end{array}$ & $\begin{array}{l}\text { To ensure high quality and tailored support for efforts to scale up nutrition in line with } \\
\text { both national and global targets (e.g., the } 6 \text { targets set at the } 2012 \text { World Health } \\
\text { Assembly). }\end{array}$ \\
\hline Stop TB Partnership & http://www.stoptb.org/ & $\begin{array}{l}\text { To serve every person who is vulnerable to TB and ensure that high-quality diagnosis, } \\
\text { treatment and care is available to all who need it. }\end{array}$ \\
\hline TB Alliance & $\begin{array}{l}\text { http:// } \\
\text { www.tballiance.org/ }\end{array}$ & $\begin{array}{l}\text { To dedicate its organisation to the discovery and development of better, faster-acting, } \\
\text { and affordable TB drugs that are available to those who need them. }\end{array}$ \\
\hline $\begin{array}{l}\text { The Global Alliance for Clean } \\
\text { Cookstoves }\end{array}$ & $\begin{array}{l}\text { http:// } \\
\text { cleancookstoves.org/ }\end{array}$ & $\begin{array}{l}\text { To save lives, improve livelihoods, empower women, and protect the environment by } \\
\text { creating a thriving global market for clean and efficient household cooking solutions. }\end{array}$ \\
\hline The Global Fund & $\begin{array}{l}\text { http:// } \\
\text { www.theglobalfund.org/ } \\
\text { en/ }\end{array}$ & $\begin{array}{l}\text { To attract, manage and disburse additional resources through a new PPP that will make } \\
\text { a sustainable and significant contribution to the reduction of infections, illness and } \\
\text { death, thereby mitigating the impact caused by HIV/AIDS, TB and malaria in countries } \\
\text { in need, and contributing to poverty reduction as part of the MDGs. }\end{array}$ \\
\hline $\begin{array}{l}\text { The Global Public-Private Part- } \\
\text { nership for Handwashing }\end{array}$ & $\begin{array}{l}\text { http:// } \\
\text { globalhandwashing.org/ }\end{array}$ & $\begin{array}{l}\text { To drive forward, develop, and share knowledge to strengthen handwashing } \\
\text { implementation, build political commitment, and trigger action to promote } \\
\text { handwashing at local, national, and international levels, including through advoacy } \\
\text { initiatives, such as Global Handwashing Day. }\end{array}$ \\
\hline $\begin{array}{l}\text { The Micronutrient Initiative } \\
\text { (Nutrition International) }\end{array}$ & $\begin{array}{l}\text { http:// } \\
\text { www.nutritionintl.org/ }\end{array}$ & $\begin{array}{l}\text { To be a global leader in advancing integrated, innovative and sustainable solutions to } \\
\text { reduce vitamin and mineral deficiencies through advocacy, technical and } \\
\text { programmatic support, in collabortion with others. }\end{array}$ \\
\hline $\begin{array}{l}\text { The Partnership for Maternal, } \\
\text { Newborn and Child Health }\end{array}$ & $\begin{array}{l}\text { http://www.who.int/ } \\
\text { pmnch/en/ }\end{array}$ & $\begin{array}{l}\text { To increase the engagement, alignment and accountability of partners, by creating a } \\
\text { multi-stakeholder platform that will support the successful implementation of the Glo- } \\
\text { bal Strategy for Women's, Children's and Adolescent's Health, enabling partners to } \\
\text { achieve more together than any individual Partner could do alone. }\end{array}$ \\
\hline
\end{tabular}

to the specific health needs of women and girls or men and boys.

The governing bodies of identified GPPPH contained between 8 and 27 members; only one partnership (Partnership for Maternal, Newborn and Child Health) had equal numbers of women $(n=12)$ and men $(n=12)$ on its board, while Stop TB was close to parity with 12 women and 13 men. For one partnership (Handwashing) it was not possible to identify the gender breakdown of the board since the website listed organisations rather than individuals, and its secretariat did not respond to our request for information. The other 15 partnerships had governing bodies with more men than women, with a gender ratio of up to five times more men than women (Roll Back Malaria). GAVI was the only partnership with a stated policy of gender equality on its governing board, 


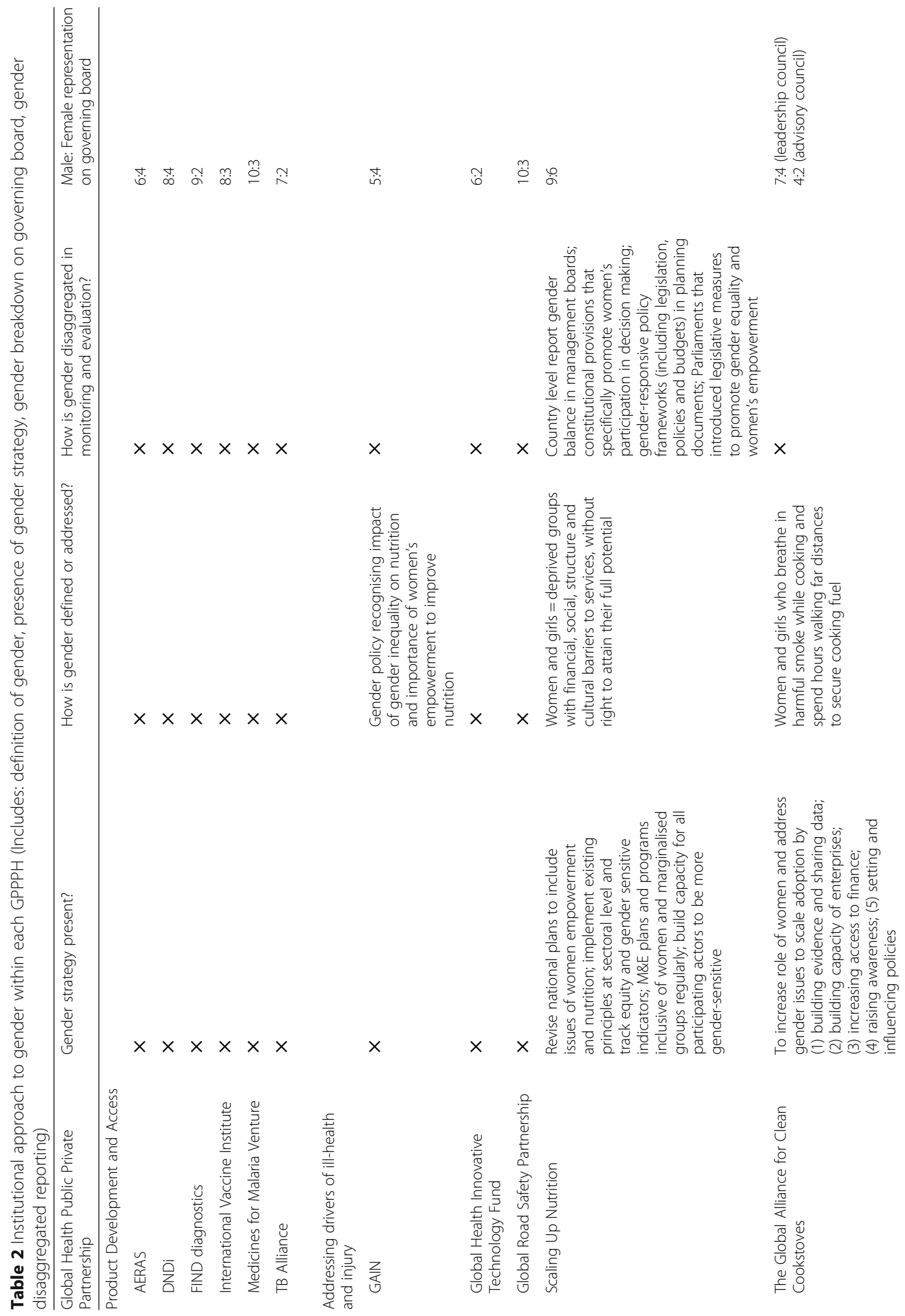




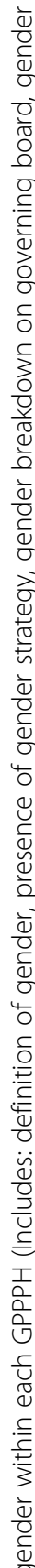

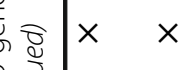

오

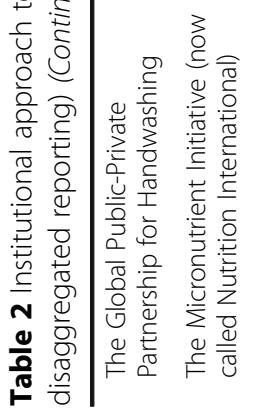

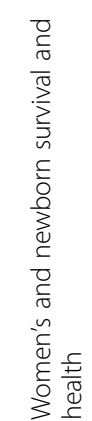

$\times \quad 3 \stackrel{0}{1}$

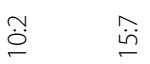

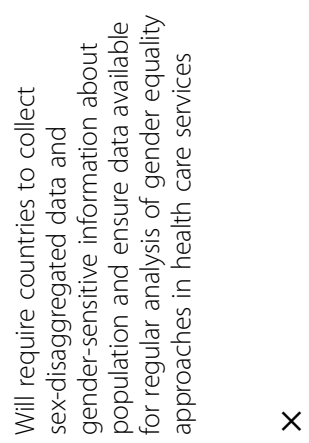

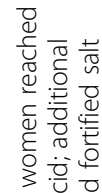

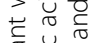

它㐾选

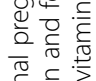

든

要紊

\%

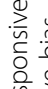

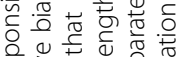

Q

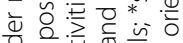

范范言

i.

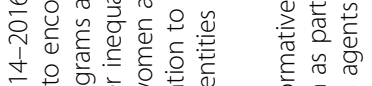

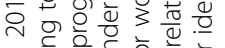

든

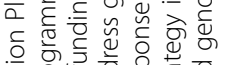

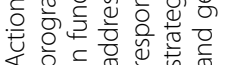

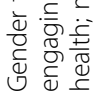

$\stackrel{\sim}{\check{\Perp}}$

远完

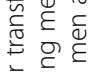

$\stackrel{\stackrel{\sim}{\check{r}}}{\sim}$

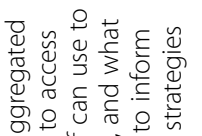

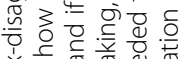

凶.

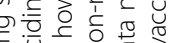

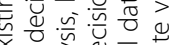

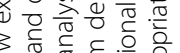

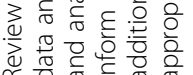

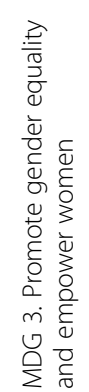

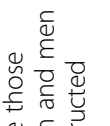

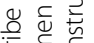

岕

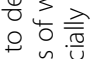

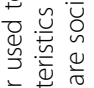

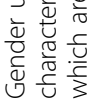

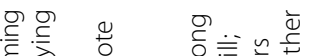

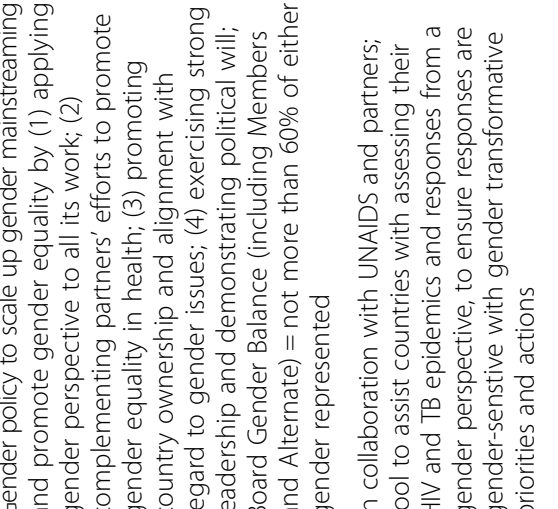

$\stackrel{\sim}{\stackrel{m}{\sim}}$

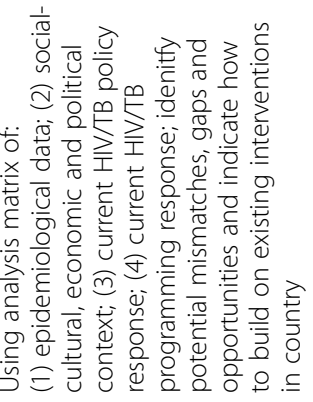

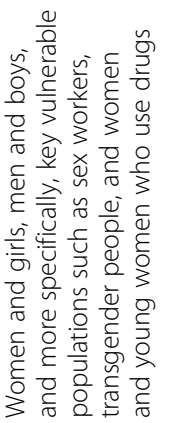


and they have 15 men and 12 women. Of note, women from the private sector were proportionally more underrepresented than women in public/other sectors and ten of the 18 boards had no female private sector representation.

Very few of the partnerships reported sex- or genderdisaggregated data in their annual reports or available coverage/impact results. Since 2014, GAVI requires countries to specify when their proposals target a gender-related barrier to immunisation (specified by $39 \%$ of proposals to date) and the Scaling Up Nutrition partnership 2015 report mentions that 22 countries have gender responsive allocations, with nutrition data reported for women but not men. The Micronutrient Initiative details the number of women reached through its work. None of the partnerships which focus on the health of infants and children (e.g., through nutritional support or vaccines) provide sex-disaggregated data.

The 18 GPPPH ranged in focus from single issue (e.g., development of a vaccine) to population-wide (e.g., focus on health of mothers and children), with particular attention paid to infectious and communicable diseases in childhood. The majority of the initiatives (12/18) were concerned with the infectious and communicable diseases, three partnerships focused on nutrition (particularly malnutrition and deficiencies), and one was crosscutting (Partnership for Maternal, Newborn and Child Health). None of the partnerships addressed the noncommunicable diseases (NCDs) directly, but two of these addressed their determinants: the Global Alliance for Clean Cookstoves (focus on reducing indoor air pollution), and the Global Road Safety Partnership (working to reduce road-crash deaths and injuries).

\section{Discussion}

Global public private partnerships in health have transformed the global health landscape over the past $20+$ years, and the role of these partnerships has recently been strengthened with the adoption of the Agenda for Sustainable Development, which also commits the global community to achieving gender equality and empowerment of all women and girls (Goal 5). GPPPH are an important, although contested, component of the global response to contemporary global health challenges and several calls have been made to evaluate their effectiveness and the equity implications of the work they fund $[38,39]$. Such evaluation, we argue, should include an analysis of how GPPPH perceive and address underlying social and structural determinants of health - including gender inequality and discrimination.

We found that gender is most often absent from the core strategies and policies of GPPPH, or, if present, suggest a wide variation in the understanding of gender largely conceived as pertaining to women and girls. Such focus manifests in recognition of increased vulnerability of women and girls to ill-health (e.g., GAIN, Global Alliance for Clean Cookstoves, Micronutrient Initiative), women/girls' lack of agency to redress a health problem (GAIN), or the higher care burden that often falls upon girls and women (Roll Back Malaria). Stop TB is one of the very few partnerships promoting the use of a gender-assessment tool to guide its work, yet its country level data is not disaggregated for gender specific differences in risks, health seeking and programme outreach. The Global Fund's gender strategy is strong in its commitment to addressing gender inequalities that fuel the HIV epidemic (with a focus on women and girls), yet evaluation of its implementation and monitoring indicators suggests a major gap between policy intent and practice with too few grant agreements found to specify, fund or monitor gender-sensitive or transformative activities [40, 41].

The majority of GPPPH, however, are gender blind in their approach to health and lack simple mechanisms for enhancing gender accountability. Three notable omissions and gaps to gender transformative global health policies and programmes emerge from our analysis.

First, the vast majority of partnerships were governed by boards with unequal gender ratios (Table 1). The skewed composition of governing bodies of GPPPH, reflected in the conspicuous invisibility of women, reinforces concerns around tokenistic pursuit of goals of representation and rights by global health actors [42] and raises concerns for accountable governance in global health.

Second, the majority of GPPPH fail to report or publish sex-disaggregated data on coverage, outcomes or impact of the programmes they fund (Table 2). Where gender specific outcomes are reported, these are largely restricted to presenting what percentage of beneficiaries are women and girls. Such a view is not only limiting but may be counterproductive to tackling the underlying determinants of the global burden of disease. Sex and age data disaggregation on risk exposure, prevention and treatment coverage and outcomes are essential for understanding illhealth, ensuring investments are reaching those with highest need, and monitoring impact - including impact on reducing gender-based gaps in coverage and outcomes. Such information is vital to the work of ensuring that noone is left behind in global health. For example, a systematic analysis of global incidence and mortality associated with HIV, TB and malaria over more than two decades found that mortality rates were higher in males than females for all three infections, while incidence rates were higher in females for malaria, higher in men for TB, and approximately equal for HIV [43] . A gendered interpretation of this picture may conclude that programmes concerned with gender norms around treatment seeking and health care coverage will need to include a focus on higher mortality rates in men (as an indicator of lower access to care) - but among our sample of partnerships, only Stop 
TB seems to be concerned with this dimension of gender. Holding GPPPH to account for gender and health outcomes means, at a minimum, having up-to-date sexdisaggregated data on coverage and outcomes.

Third, as shown in the two Figures, the partnerships have clustered the focus of their work on maternal health, child health and communicable/infectious diseases. The absence of any substantial body of GPPPH activity in addressing the highest burdens of disease (i.e., the non-communicable diseases and violence and injuries) represents a gross failure not only of evidence-informed resource allocation, but also a failure to recognize the gendered nature of health risks and suffering. Large proportions of the NCDs and their underlying risk behaviours, are currently more common in men and boys (e.g., diseases associated with tobacco, alcohol, occupational health exposures) [44] but rates of exposure are rising in women [45] - and will soon be followed by increased incidence of NCD-related ill-health. It has been argued (including by us [22]) that much of this risk behavior is influenced by profit-driven industries (e.g., consumption of tobacco [42], alcohol [43], highly processed foods [46]). Failure to address these areas signals a major abrogation of responsibility from the global health community. This lack of attention echoes the wider criticism of GHPPPs that the business-orientation endorsed by them has a bias for 'safe issues' [47] and narrow technical or 'magic bullet' approaches over tackling structural and more complex upstream determinants, including gender power relations $[4,15]$.

\section{Conclusions}

The GPPPH are important players in global health. They constitute a major source of funding for health programmes in low- and middle-income countries, and exert influence over health decision-making at national and global levels. Therefore, understanding how the GPPPH address gender - a key determinant of health outcomes - raises legitimate issues of priority-setting, resource allocation and accountability.

Our finding of a widespread lack of a gender-aware approach within these partnerships is not unexpected, as similar results have been found in reviews of other major global health institutions [21, 22]. Nonetheless, gender equity should be central to the work that they do. Gender drives not only the risk of exposure to an illnessdeterminant, but also has a major influence over the likelihood that appropriate prevention, care and treatment services will be either sought, offered or received. Of equal and potentially greater concern, is the finding of an almost total absence of GPPPH activity to address the gendered nature of major health risks being faced by both women and men globally - in light of the growing burden of NCDs.
We believe that two lines of action are now needed. First, the existing GPPPH need to become more serious about how they "do gender". It is not sufficient to mention girls and women in advocacy documents. Instead, a relational perspective on gender needs to be mainstreamed through the regular activities, deliverables and systems of accountability of all GPPPH - from boardroom to delivery/access to health services, gender needs to be fully taken into account.

Second the global health community needs to place much greater emphasis on tackling the major burdens of NCDs, including the gendered nature of risk for many of the NCDs. Whether GPPPH are the most appropriate model for tackling NCDs remains open to question. Given the key role that the private sector plays in determining the nature of risk (including manufacturing gendered risks) of exposure to healthreducing products, there is a strong argument for the need for interaction between global health communities and private companies. However, the broad yet specific challenge is how to manage the risks inherent in such interactions [48], mitigate conflicts of interest, and ensure that population health is protected [49] while also addressing the gendered nature of health determinants and health system responses.

\section{Endnotes}

${ }^{1}$ Data not included in the Table, but available

\section{Acknowledgements}

Not applicable

\section{Disclaimer}

The views expressed in this paper do not necessarily reflect those of UNAIDS.

Funding

No funds were received for this work.

Availability of data and materials

Data sharing is not applicable to this article as no datasets were generated or analysed during the current study.

\section{Authors' contributions}

$\mathrm{SH}, \mathrm{KB}$ and $\mathrm{AK}$ conceived of the paper, wrote drafts and approved the final document. SH and KB analysed the make-up of governing bodies.

Authors' information

Not applicable

Competing interests

The authors declare that they have no competing interests.

Consent for publication

Not applicable

Ethics approval and consent to participate

Not applicable for secondary data analysis of publicly available materials.

\section{Publisher's Note}

Springer Nature remains neutral with regard to jurisdictional claims in published maps and institutional affiliations. 


\section{Author details}

IInstitute for Global Health, University College London, 30, Guilford Street, London WC1N 1EH, UK. ${ }^{2}$ UNAIDS, Geneva, Switzerland. ${ }^{3}$ Global Public Health Unit, University of Edinburgh, Edinburgh, UK.

\section{Received: 6 December 2016 Accepted: 20 April 2017 Published online: 12 May 2017}

\section{References}

1. Bovaird T. Public-private partnerships: From contested concepts to prevalent practice. Int Rev Adm Sci. 2004;70(2):199-215.

2. Ciccone DK. Arguing for centralized coordination solution to the publicprivate partnership explosion in global health. Glob Health Promot. 2010;17(2):48-51.

3. Rosenau PV. Public-private policy partnerships. Cambridge: MIT Press.; 2000.

4. McCoy D, Chand S, Sridhar D. Global Health Funding: how much, where it comes from and where it goes. Health Policy Plan. 2009;24(6):407-17.

5. World Health Organization Maximizing Positive Synergies Collaborative Group. An assessment of interactions between global health initiatives and country health systems. Lancet. 2009;373:1237-2169.

6. Stevenson MA. The relevance of the public private partnership paradigm to the prevention of diet-associated non-communicable diseases in wealthy countries. Glob Public Health. 2015;10(8):930-46.

7. Martin M, Halachmi A. Public-Private Partnerships in global health: addressing issues of public accountability, risk management and governance. Public Affairs. 2012;36(2):189-237.

8. Data on Global Health Financing from Institute for Health Metrics and Evaluation; available at http://vizhub.healthdata.org/fgh/ Accessed 03 Nov 16

9. Lee K, Humphreys D, Pugh M. "Privatisation" in the United Nations System: Patterns of Influence in Three Intergovernmental Organisations'. Glob Soc J Interdisciplinary Int Relat. 1997;11(3):339-57.

10. Buse K, Harmer A. Power to the Partners?: The Politics of Public-Private Health Partnerships. Development. 2004;47(2):49-56.

11. Kapilashrami A, McPake B. Transforming governance or reinforcing hierarchies and competition: examining the public and hidden transcripts of the Global Health initiatives and HIV in India. Health Policy Plan. 2013;28(6):626-35.

12. Wu D, Hawkes S, Buse K. Prevention of mother-to-child transmission of syphilis and HIV in China: what drives political prioritization and what can this tell us about promoting dual elimination? Int J Gynaecol Obstet. 2016;130(1):S32-6.

13. Buse K, Walt G. Global Public-Private Partnerships: Part I - A New Development in Health? Bull World Health Organ. 2000;78(4):549-61.

14. Buse K, Walt G. Global Public-Private Partnerships: Part II - What are the health issues for global governance? Bull World Health Organ. 2000;78(5):699-709.

15. Birn A. "Philanthrocapitalism, Past and Present: The Rockefeller Foundation, the Gates Foundation, and the Setting(s) of the International/global Health Agenda." Hypothesis 2014;12 (1). doi:10.5779/hypothesis.v12i1.229.

16. Storeng KT. The GAVI Alliance and the 'Gates Approach' to Health System Strengthening. Global Public Health. 2014;9(8):865-79.

17. United Nations General Assembly, Resolution adopted by the General Assembly on 25/09/15. Transforming our world: the 2030 Agenda for Sustainable Development. Available at: http://www.un.org/ga/search/view_ doc.asp?symbol=A/RES/70/1\&Lang=E Accessed 03 Nov 16 (para 17.17).

18. United Nations. Addis Ababa Action Agenda of the Third International Conference on Financing for Development, New York, 2015. 2015. p. 24. Accessible at: http://www.un.org/esa/ffd/wp-content/uploads/2015/08/ AAAA_Outcome.pdf Accessed 18 Oct 16.

19. Zammit A. Development at Risk: Rethinking UN-Business Partnerships. Geneva: UNRISD and South Centre; 2003. Accessible at: http://www2.ohchr.org/english/ issues/globalization/business/docs/report5.pdf Accessed 03 Oct 16.

20. Buse K, Harmer A. Seven habits of highly effective global public-private health partnerships: practice and potential. Soc Sci Med. 2007;64(2):259-71.

21. Payne $\mathrm{S}$. Gender mainstreaming as a global policy paradigm: barriers to gender justice in health. J Int Comp Soc Policy. 2014;30(1):28-40.

22. Hawkes S, Buse K. Gender and global health: evidence, policy and inconvenient truths. Lancet. 2013;381:1783-7.

23. UN Women. Gender Mainstreaming. Accessible at: http://www.un.org/ womenwatch/osagi/gendermainstreaming.htm Accessed 03 Oct 16.
24. Kennett P, Payne S. Gender justice and global policy paradigms. J Int Comp Soc Policy. 2014;30(1):1-5. doi:10.1080/21699763.2014.887027.

25. United Nations Economic and Social Council. Mainstreaming the gender perspective into all policies and programmes in the United Nations system. Decision 1997/2. Accessible at: http://www.un.org/documents/ecosoc/docs/ 1997/e1997-66.htm Accessed 20 Mar 17.

26. Tolhurst R, Leach B, Price J, Robinson J, Ettore E, Scott-Samuel A, Sabuni LP, Kapilashrami A, Bristow K, Theobald S. Intersectionality and gender mainstreaming in international health: Using a feminist participatory action research process to analyse voices and debates from the global south and north. Soc Sci Med. 2012;74(11):1825-32.

27. Walby S. Gender mainstreaming: Productive tensions in theory and practice. Soc Polit Int Stud Gend State Society. 2005;12(3):321-43.

28. Hanefeld J, Spicer N, Brugha R, et al. How have global health initiatives impacted on health equity?' A literature review commissioned by the health systems knowledge network. 2007. Available at: http://www.who.int/social_ determinants/resources/csdh_media/global_health_initiatives_2007_en.pdf Accessed 01 Oct 16

29. Gideon J, Porter F. Unpacking 'women's health' in the context of PPPs: A return to instrumentalism in development policy and practice? Global Soc Policy. 2016;16(1):68-85.

30. Ravindran TKS, Kelkar-Khambete A. Gender mainstreaming in health: looking back, looking forward. Global Public Health. 2008;3(1):121-42.

31. WHO: Partnerships and Collaborative Arrangements with WHO Involvement. http://www.who.int/about/who_reform/partnerships-collaborativearrangements-with-WHO-involvement.pdf?ua=1 Accessed 20 Mar 17.

32. WHO. Gender mainstreaming for health managers: a practical approach. Accessible at: http://www.who.int/gender-equity-rights/knowledge/health_ managers_guide/en/ Accessed 20 Mar 17.

33. How to do gender analysis in health systems research: A guide. http:// resyst.lshtm.ac.uk/resources/how-do-gender-analysis-health-systemsresearch-guide Accessed 20 Mar 17.

34. Institute for Health Metrics and Evaluation. Data available at: http://www. healthdata.org/data-visualization/gbd-compare Data accessed 18 Oct 16.

35. Global Fund Gender Equality Strategy. Accessible at: https:/www.theglobalfund. org/media/1250/core_genderequality_strategy_en.pdf Accessed 20 Mar 17.

36. Stop TB Partnership: Stop TB Partnership Operational Strategy 2016-2020. Accessible at: http://www.stoptb.org/assets/documents/about/27-4. 1\%20Stop\%20TB\%20Partnership\%20Operational\%20Strategy\%202016-2020. pdf Accessed 03 Oct 16.

37. Stop TB Partnership. News Stories 2016. Available at: http://www.stoptb.org/ news/stories/2016/ns16_030.asp Accessed 03 Oct 16.

38. Torchia M, Calabro A, Morner M. Public-Private Partnerships in the Health Sector: A systematic review of the literature. Public Manage Rev. 2013;17(2):236-61.

39. Asante $A D, Z$ wi AB. Public private partnerships and global health equity: prospects and challenges. Indian J Med Ethics. 2007;4(1):176-80.

40. Gorna R. Global Fund Programmes are far from being Gender Transformative. 2012. Accessible at: http://www.aidspan.org/gfo_article/global-fundprogrammes-are-far-being-gender-transformative Accessed 03 Oct 16.

41. Garmaise D. Gender Equality Experts Criticise Implementation of Global Fun's Gender Equality Strategy. Accessible at: http://www.aidspan.org/gfo_article/ gender-equality-experts-criticise-implementation-global-fund\%E2\%80\%99s-gestrategy Accessed 03 Oct 16

42. Kapilashrami A, Fustukian S, McPake B. Global prescriptions and neglect of the 'local': What lessons for global health governance has the Framework Convention on Global Health learnt? Global Health Governance, vol. Volume IX : 1 (2015 Spring-Fall Combined) ISSN 1939-2389. 2015.

43. Murray CJL, Ortblad KF, Guinovart C, Lim SS, Wolock TM, Allen Roberts D, et al. Global, regional and national incidence and mortality of HIV, tuberculosis and malaria during 1990-2013: a systematic analysis for the Global Burden of Disease Study 2013. Lancet. 2014;384:1005-70.

44. Gilmore AB, Fooks G, Drope J, Bialous SA, Jackson RM. Exposing and addressing tobacco industry conduct in low-income and middle-income countries. Lancet. 2015;385:1029-43.

45. Slade T, Chapman C, Swift W, Keyes K, Tonks Z, Teeson M. Birth cohort trends in the global epidemiology of alcohol use and alcohol-related harms in men and women: systematic review and metaregression. BMJ Open. 2016. doi:10.1136/bmjopen-2016-011827.

46. Stuckler D, Nestle M. Big Food, Food Systems, and Global Health. PLoS Med. 2012;9(6):e1001242. doi:10.1371/journal.pmed.1001242. 
47. Eckl J. The power of private foundations: Rockefeller and Gates in the struggle against malaria. Global Social Policy. 2014;14:91-116.

48. Hawkes C, Buse K. Public health sector and food industry interaction: it's time to clarify the term 'partnership' and be honest about underlying interests. Eur J Pub Health. 2011;21(4):400-1.

49. Buse K, Hawkes S. Sitting on the FENSA: WHO engagement with industry. Lancet. 2016;388:446-7.

Submit your next manuscript to BioMed Central and we will help you at every step:

- We accept pre-submission inquiries

- Our selector tool helps you to find the most relevant journal

- We provide round the clock customer support

- Convenient online submission

- Thorough peer review

- Inclusion in PubMed and all major indexing services

- Maximum visibility for your research

Submit your manuscript at www.biomedcentral.com/submit
Biomed Central 